\title{
PCR WITH Paracoccidioides brasiliensis SPECIFIC PRIMERS: POTENTIAL USE IN ECOLOGICAL STUDIES
}

\begin{abstract}
SUMMARY
The precise microenvironment of Paracoccidioides brasiliensis has not yet been discovered perhaps because the methods used are not sensitive enough. We applied to this purpose the polymerase chain reaction (PCR) using three sets of specific primers corresponding to two $P$. brasiliensis genes. This fungus as well as several other fungi, were grown and their DNA obtained by mechanical disruption and a phenol chloroform isoamylalcohol-based purification method. The DNA served for a PCR reaction that employed specific primers from two $P$. brasiliensis genes that codify for antigenic proteins, namely, the $27 \mathrm{kDa}$ and the $43 \mathrm{kDa}$. The lowest detection range for the $27 \mathrm{kDa}$ gene was $3 \mathrm{pg}$. The amplification for both genes was positive only with DNA from $P$. brasiliensis; additionally, the mRNA for the $27 \mathrm{kDa}$ gene was present only in $P$. brasiliensis, as indicated by the Northern analysis. The standardization of PCR technology permitted the amplification of P. brasiliensis DNA in artificially contaminated soils and in tissues of armadillos naturally infected with the fungus. These results indicate that PCR technology could play an important role in the search for $P$. brasiliensis' habitat and could also be used in other ecological studies.
\end{abstract}

KEYWORDS: P. brasiliensis; PCR detection; Specific primers; Soil and animal detection.

\section{INTRODUCTION}

Paracoccidioides brasiliensis is the dimorphic fungus responsible for paracoccidioidomycosis (PCM), a disease highly prevalent in Latin America $^{6}$. Skin testing studies carried out in areas of endemicity have shown a relative high frequency of reactivity $(\geq 12 \%)$ in healthy persons. However, only a few of these will develop the disease later on. The absence of epidemic outbreaks and the long periods of latency of the mycosis hinder determination of the source of the primary contact ${ }^{6}$. PCM endemic areas have certain ecological characteristics which suggest that the following factors favor the presence of $P$. brasiliensis: temperatures between 17 to $24{ }^{\circ} \mathrm{C}$, high humidity with annual pluviosities ranging from 500 to $2,500 \mathrm{~mm}$, abundant forests and watercourses, short winters and rainy summers ${ }^{12}$.

The precise microenvironment of $P$. brasiliensis has not yet been discovered, although its habitat is considered to be exogenous to $\operatorname{man}^{24}$. The fungus has been rarely isolated from natural sources, such as soils; as an example, it was isolated once from Argentinean soil ${ }^{22}$, twice from the same farm in Venezuela ${ }^{1}$, and once from a coffee growing area in Brazi $^{27}$. Additionally the fungus has been isolated from dog food ${ }^{11}$, bats and penguin excreta ${ }^{14,15}$; nonetheless, numerous attempts to repeat these observations have failed ${ }^{24}$.
In the past, the disease had rarely been informed in animals; more recently, however, the presence of the fungus has been repeatedly reported in armadillos (Dasypus novemcinctus). These isolations have been confirmed in different paracoccidioidomycosis endemic areas of Brazil. The armadillos become infected in nature and as such, they are enzootic hosts to P. brasiliensis ${ }^{3,9,21}$.

The search for the natural habitat of $P$. brasiliensis using conventional techniques has been difficult. The application of molecular biology procedures, specifically, the polymerase chain reaction (PCR) technique may prove more appropriate to detect this pathogenic fungus, as it has high sensitivity and specificity ${ }^{16}$. Additionally, it can also be applied to detection of environmental microorganisms ${ }^{17,31}$; when used to amplify DNA in soil samples, the procedures may be hindered by the presence of natural contaminants such as polysaccharides and/or humic acids, two powerful PCR inhibitors, which interfere with the reaction ${ }^{2,4,28}$.

An essential step for the development of PCR for P. brasiliensis is the designing of specific primers. We have approached this step by means of two genes, one that codifies for the $43 \mathrm{kDa}$ glycoprotein, an immunodominant antigen ${ }^{8}$ and the other codifying for the $27 \mathrm{kDa}$ protein, also an antigenic protein. The latter has been the second P. brasiliensis gene to be cloned, sequenced and characterized ${ }^{18,19,23}$.

(1) Unidad de Biología Molecular y Grupo de Micología, Corporación para Investigaciones Biológicas (CIB), Medellín, Colombia.

(2) Facultad de Medicina Veterinaria y Zootecnia, Universidad de Caldas, Manizales, Colombia.

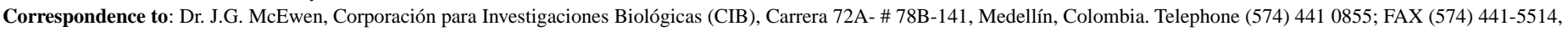
Email: mcewen@epm.net.co 


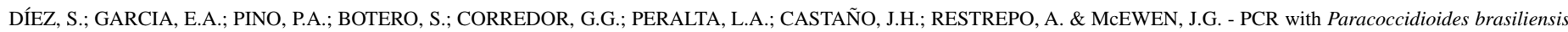
specific primers: potential use in ecological studies. Rev. Inst. Med. trop. S. Paulo, 41(6): 351-357, 1999.

We report here on the attemp to standardize a PCR technique using primers designed to match two specific sequences of $P$. brasiliensis, for amplification in artificially contaminated soils as well as in the tissues of naturally infected armadillos, captured in an endemic area for paracoccidioidomycosis in Colombia.

\section{MATERIALS AND METHODS}

The different fungi that were studied were grown and their total RNA and genomic DNA extracted and analyzed by Northern-blot and PCR, respectively. Additionally, DNA was extracted both from negative soil samples artificially contaminated with $P$. brasiliensis and tissues obtained from armadillos captured in an endemic area. These materials were used as the template for a PCR reaction that used $P$. brasiliensis specific primers (Table 1).

\section{Culture conditions}

P. brasiliensis isolates B 339 (ATCC 32069) and Gar (ATCC 60855), Candida albicans (ATCC 90028), Saccharomyces cerevisae (ATCC 9763), Cryptococcus neoformans (ATCC 90112), Histoplasma capsulatum var capsulatum Hc1980, Sporothrix schenkii CIB 37405, Aspergillus fumigatus CIB 214 were obtained from the culture collection of the CIB, and Blastomyces dermatitidis was obtained from the MAMH 3559, Alberta University, Canada. P. brasiliensis and H. capsulatum were grown for 10-12 days in a gyratory shaker set at $120 \mathrm{rpm}$ (Gallenkamp, Leicester, England) both in the mycelial and yeast phases, in the modified liquid synthetic medium of McVeigh and Morton ${ }^{25}$, at their optimal growth temperatures $\left(26^{\circ} \mathrm{C}\right.$ and $36^{\circ} \mathrm{C}$, respectively). C. albicans and $A$. fumigatus were grown in Sabouraud liquid medium supplemented with L-asparagine $(0.14 \%)$ and thiamine $(0.01 \%)$, at $22{ }^{\circ} \mathrm{C}\left( \pm 4{ }^{\circ} \mathrm{C}\right)$ in a gyratory shaker for 8 days. B. dermatitidis, S. schenkii, S. cerevisae, and C. neoformans, were grown in the same medium but at $37^{\circ} \mathrm{C}$.

\section{Armadillos}

As previously described ${ }^{9}$ the area where the armadillos were captured was selected, on the basis of the records corresponding to patients with paracoccidioidomycosis, in the Department of Caldas, Colombia. Particular attention was given to those cases that have lived and worked within the same locality; we selected a coffee growing terrain. This place has ecological conditions favorable to the growth of $P$. brasiliensis and it corresponds simultaneously, to the habitat of the nine-banded armadillo $^{9}$. Permission for capture of armadillos was obtained from the wild-life preservation authorities (Instituto Colombiano Agropecuario ICA, Corpocaldas branch of ICA). Four male adults and one female adult $D$. novemcinctus were captured within a period of 6 months. The animals were sacrificed by prolonged anesthesia ${ }^{9}$. Samples from the liver, the spleen, the lungs, and the mesentheric lymph nodes were cultured, used for animal inoculation and PCR.

\section{Processing of tissues from armadillos for culture and inoculation}

The technique used for the study of animal tissues can be summarized as follows 9 : biopsies were minced and/or homogenized in tissue grinders and splited in three portions, one of which was then plated in Sabouraud dextrose agar and Mycosel agar (BBL, Beckton Dickinson Microbiology
Systems, Cockeysville, MD, USA) and incubated under appropriate conditions. When growth occurred, microscopic observations were carried out and the mycelial growth sub-cultured at $36{ }^{\circ} \mathrm{C}$ in Sabouraud glucose agar with thiamine and asparagine, both at $0.1 \%$, with incubation at $36{ }^{\circ} \mathrm{C}$, in order to facilitate conversion to the yeast phase. Colonies developing here were subjected to microscopic observation. Other portion of the homogenized tissues was used for the intraperitoneal inoculation of adult, male BALB/c mice, 4 per tissue. These mice were sacrificed after 8 weeks and the lungs, spleen, liver and mesenteric lymph nodes, cultured as indicated above ${ }^{9}$. The remaining tissue homogenates were subjected to molecular biology procedures, as described below.

\section{Artificial contamination of soils with $P$. brasiliensis}

Fresh garden soil (1g) was contaminated with different quantities of P. brasiliensis isolate B339 in the mycelial phase $\left(1.5 \times 10^{5}-20 \times 10^{6}\right.$ cells $)$. The quantification of the inoculum was done as described by ESPINELINGROFF \& KERKERING ${ }^{10}$. The inoculated soils were resuspended in 6 volumes of EDTA $0.125 \mathrm{M}$ and 6 volumes of extraction buffer (2\% triton $\mathrm{x}-100,1 \%$ SDS, $100 \mathrm{mM} \mathrm{NaCl}, 10 \mathrm{mM}$ Tris- $\mathrm{HCl}$ [pH 8.0], 1mM EDTA). Prior to DNA extraction, these soils were shaken at $100 \mathrm{rpm}$ overnight (Gallenkamp, Leicester, England) at room temperature.

\section{Northern blot analysis of the p27 gene}

Total RNA was extracted using Trizol ${ }^{\mathrm{TM}}$ (GIBCO BRL, Gaithersburg, MD), from the fungi described above, except for A. fumigatus and $S$. schenckii which were not used in the Northern blot analysis. These RNAs were run in agarose gel, transferred to nylon membranes and visualized with ethidium bromide. The probe corresponding to a $536 \mathrm{bp}$ from the gene's sequence that codifies for the $27 \mathrm{kDa}$ protein ${ }^{19}$ was obtained by PCR, using primers LO/UP (Table 1) and labelled using the Fluorescein Gene Images $^{\mathrm{TM}}$ from Amersham (Buckinghamshire, UK). The probes were then exposed in the nylon membrane (Probe to X-ray film) for 2 hours $^{26}$.

\section{DNA Fungal extraction}

The DNA was extracted by mechanical disruption as reported by VAN BURIK et al. (method 1) $)^{30}$, with minor modifications, as follows: fungal growth was transferred to micro-centrifuge tubes and suspended in $400 \mu \mathrm{l}$ of extraction buffer as described above; mechanical disruption of the fungal suspension was achieved by means of glass beads; a extraction with $400 \mu \mathrm{l}$ phenol/chloroform/iso-amyl alcohol (PHE/CHL/ IAA) (25:24:1 was done with vortexing for 30 minutes, (Genie 2, Fisher Scientific, New York, USA). The aqueous layer was re-extracted twice with an equal volume of PHE/CHL/IAA (25:24:1), and once with equal volume of (chloroform/iso-amyl alcohol) CHL/IAA (24:1), then precipitated with ammonium acetate and ethanol ${ }^{26}$. The DNA pellet was resuspended in $100 \mu \mathrm{L}$ of TE buffer (10 mM tris [pH 8.0], 1 mM EDTA); RNAse treatment was done with $2 \mu \mathrm{l}(2 \mathrm{mg} / \mathrm{ml})$ ribonuclease A (Sigma, St Louis, USA) at $37^{\circ} \mathrm{C}$ for one hour. To remove residual cellular debris, an additional extraction with PHE/CHL/IAA and CHL/IAA was done and the DNA pellet finally resuspended in $100 \mu \mathrm{l}$ of TE buffer. The DNA obtained was measured by spectrophotometry at $260 \mathrm{~nm}$, and its purity was determined by the ratio $\mathrm{A}_{260 / 280}$. In order to determine the minimal concentration that could be detected by PCR, the extracted DNA was serially diluted (1ug-1pg per reaction). 


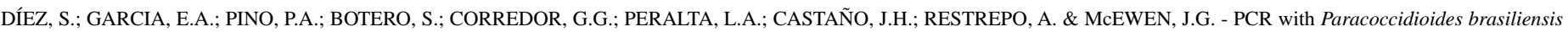
specific primers: potential use in ecological studies. Rev. Inst. Med. trop. S. Paulo, 41(6): 351-357, 1999.

Table 1

Primers used for PCR amplifications

\begin{tabular}{|c|c|c|c|c|}
\hline \multirow[t]{2}{*}{ Primers } & Sequence & \multicolumn{2}{|c|}{$\begin{array}{c}\text { Amplification conditions } \\
\text { Temperature }\left({ }^{\circ} \mathrm{C}\right) \& \text { time }(\mathrm{m}, \mathrm{s})\end{array}$} & $\begin{array}{c}\text { Specific amplification } \\
\text { products (bp) }\end{array}$ \\
\hline & & \multicolumn{2}{|c|}{1 cycle at $95 \times 5 \mathrm{~m}$} & \\
\hline ITS 1 & 5' TCCGTAGGTGAACCTGCGG & & $\overline{95} \times 50 \mathrm{~s}$ & \\
\hline \multirow[t]{3}{*}{ ITS 4} & 5' TCCTCCGCTTATTGATATGC & 30 cycles at & $50 \times 50 \mathrm{~s}$ & 620 \\
\hline & & & $72 \times 50 \mathrm{~s}$ & \\
\hline & & \multicolumn{2}{|c|}{1 cycle at $72 \times 7 \mathrm{~m}$} & \\
\hline & & \multicolumn{2}{|c|}{1 cycle at $95 \times 5 \mathrm{~m}$} & \\
\hline gp43-1 & 5’ ATGAATTTTAGTTCTCTTAACCTGGCTCTT & & $\overline{95} \times 1 \mathrm{~m}$ & \\
\hline \multirow[t]{3}{*}{ gp43-2 } & 5' CCTGCATCCACCATACTTCCTAGCCCA & 30 cycles at & $40 \times 1 \mathrm{~m}$ & 1303 \\
\hline & & & $72 \times 2 \mathrm{~m}$ & \\
\hline & & \multicolumn{2}{|c|}{1 cycle at $72 \times 7 \mathrm{~m}$} & \\
\hline
\end{tabular}

$\begin{array}{ll}\text { gp2 } & 5^{\prime} \text { TCACCTGTCGACACCATACTTCCTAGCCCAAATC } \\ \text { gpM } & 5^{\prime} \text { GCCATGGTCGACAATGGGCGTGGCATAGGTTCG } \\ \text { (nested) } & \end{array}$

1 cycle at $95 \times 5 \mathrm{~m}$

30 cycles at $\begin{aligned} & 95 \times 1 \mathrm{~m} \\ & 55 \times 1 \mathrm{~m} \\ & 72 \times 1 \mathrm{~m}\end{aligned}$

1 cycle at $72 \times 7 \mathrm{~m}$

1 cycle at $95 \times 5 \mathrm{~m}$

LO $\quad$ 5' CACTCTTGGCTTTGGTTGAAG

30 cycles at $\begin{aligned} & 95 \times 1 \mathrm{~m} \\ & 55 \times 1 \mathrm{~m} \\ & 72 \times 1 \mathrm{~m}\end{aligned}$

1 cycle at $72 \times 7 \mathrm{~m}$

\section{Extraction and purification of $P$. brasiliensis DNA from artificially contaminated soils}

After overnight shaking the corresponding supernatants were transferred to different tubes. These were centrifuged at 7,000 $\mathrm{x}$ g for 20 min. DNA from these pellets was extracted using the same procedure described above. In order to eliminate soil inhibitors, we employed the procedure reported by MOREIRA with some modifications ${ }^{20}$, as follows: the pellet containing DNA was resuspended in TE buffer and 1 volume of melted $1.6 \%$ low melting point agarose (GIBCO BRL, Grand Island, N.Y., USA) was added and mixed. The mixture was poured into sterile $200 \mu \mathrm{L}$ moulds prior to solidification. The agarose blocks were dialyzed against $15 \mathrm{ml}$ of TE buffer for 24 hours. This procedure was repeated using new TE buffer. PCR was done using the $2 \mu \mathrm{L}$ obtained from melted $\left(60^{\circ} \mathrm{C}\right)$ agarose blocks.

\section{Extraction of $P$. brasiliensis DNA from animal tissues}

Homogenized tissues (lymph nodes, liver, spleen) from both the armadillos and the mice inoculated with their organs were subjected to $\mathrm{PCR}^{5}$. The DNA extraction was done following the first of the 5 techniques reported by VAN BURIK et al ${ }^{30}$ with a modification, namely, the initial extraction step, as we employed grinding the liquid-nitrogen frozen sample in mortar with pestle. The DNA pellet was suspended in $10 \mu \mathrm{L}$ of TE buffer.

\section{PCR amplifications}

10ng of DNA from culture and/or from artificially contaminated soils and/or tissues of armadillos were used as the template in an PCR reaction. The final volume was $50 \mu \mathrm{L}$. The mixture used for all reactions contained 10mM Tris- $\mathrm{HCl}(\mathrm{pH} 8.8), 50 \mathrm{mM} \mathrm{KCl}, 0.1 \%$, triton $\mathrm{x}-100$, $1.5 \mathrm{mM} \mathrm{MgCl}_{2}, 0.2 \mathrm{mM}$ (each) deoxynucleoside triphosphate, $25 \mathrm{pM}$ of the primers, and $1 \mathrm{U}$ of taq DNA polymerase (Promega, Madison, USA). Amplification was done in a thermocycler (PTC-100, MJ Reseach, INC, Watertown, USA).

The primers used in this study and the amplification conditions are shown in Table 1. The following primers were employed; ITS1/ITS4 ${ }^{5,16}$, the fungal specific universal primers used as amplification controls, the $43 \mathrm{kDa} P$. brasiliensis antigenic protein gp43-1/gp43-2 and the nested primers for this protein $\mathrm{gp} 2 / \mathrm{gpM}^{8}$, as well as $P$. brasiliensis primers $\mathrm{LO} / \mathrm{UP}^{19}$, obtained from the gene that codifies for the $27 \mathrm{kDa}$ antigenic protein. The PCR products were visualized by ethidium bromide staining after electrophoresis in agarose (GIBCO BRL, Grand Island, N.Y., USA). 


\section{RESULTS}

Northern blot analysis with the p27 probe, revealed that this gene was only transcribed by $P$. brasiliensis, with a positive signal both in the mycelium and the yeast phases of the fungus; no signals were obtained with the mRNAs from other fungi (Figure 1).

The DNA extracted from fungal cells by means of glass beads plus the extraction buffer and phenol, showed to be of high quality and purity, as determined by the ratio $\mathrm{A}_{260 / 280}$ which was $>1.8$.

PCR amplification was obtained with all the primers used; thus the ITS1/ITS4 set which corresponds to universal specific fungal primers gave a positive band of $620 \mathrm{bp}$ with all the fungi evaluated (data not shown). The gp43-1/gp43-2, the gp2 gpM (nested) and the LO/UP primers were specific for $P$. brasiliensis and they only amplified with material originating from this fungus but not with those from the remaining fungi tested. Figure 2 shows the specificity obtained with the LO/UP primers. The latter primers showed to be highly sensitive, allowing amplification of low amounts (3pg) of P. brasiliensis (approximately 90 cells)

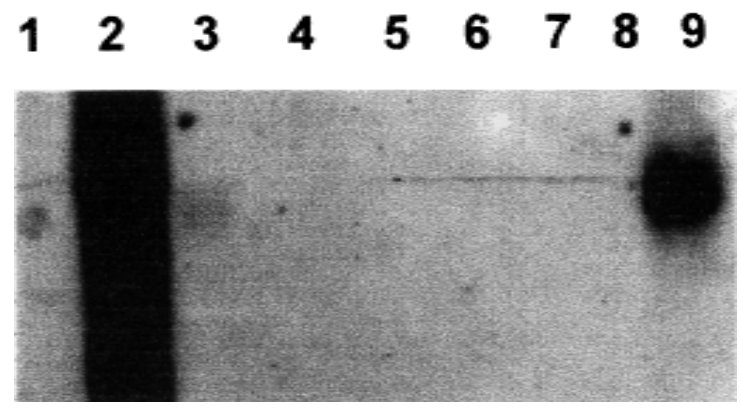

Fig. 1 - Northern-blot analysis of the p 27 gene. Lane 1. Negative control pBluescript without insert, 2. Positive control (pBluescript with gene of p27), 3. P. brasiliensis ATCC 32069 (mycelial), 4. S. cerevisae, ATCC 9763, 5. B. dermatitidis, 6. H. capsulatum, 7. C. albicans, ATCC 90028, 8. C. neoformans, ATCC 90112, 9. P. brasiliensis (yeast)
Soil samples artificially contaminated with $P$. brasiliensis, permitted amplification after elimination of the naturally contaminating PCR inhibitors. The addition of 5.0x $10^{6}$ mycelial cells of $P$. brasiliensis to 1 $\mathrm{g}$ of non-sterile sediments resulted in a larger quantity of amplified DNA. The amount of $P$. brasiliensis DNA detected by means of PCR using the species-specific primer (LO/UP) was $40 \mathrm{ng}$ (approximately $1.2 \times 10^{6}$ cells), as shown in Figure 3.

As it concerns mycological studies, primary agar cultures done with minced lymph node tissues from the first armadillo, showed growth of several colonies of a mold. These were dimorphic as demonstrated when colonies grown at room-temperature were transferred to new media and incubated at $36^{\circ} \mathrm{C}$. The corresponding cultures exhibited the multiple budding cells that characterize $P$. brasiliensis ${ }^{9}$. The products of amplification of the lymph node and liver of this first armadillo, are shown in Figure 4.

The results of mycological studies and PCR amplifications from animal tissues are shown in the Table 2.

Table 2

Results of cultures and DNA amplification in animal tissues

\begin{tabular}{cccccc}
\hline \multirow{2}{*}{$\begin{array}{c}\text { Armadillo } \\
\mathrm{N}^{\mathrm{o}}\end{array}$} & Isolation in & \multicolumn{5}{c}{ Amplification by PCR } \\
\cline { 3 - 6 } & culture & Lungs & Lymph node & Liver & Spleen \\
\hline $1^{*}$ & + & - & - & + & - \\
2 & - & - & - & - & - \\
3 & - & - & - & - & - \\
4 & - & - & - & - & - \\
5 & - & + & + & + & -
\end{tabular}

*Mice inoculated with lymph node and liver from this armadillo, were also positive by PCR (Mouse lungs and liver).

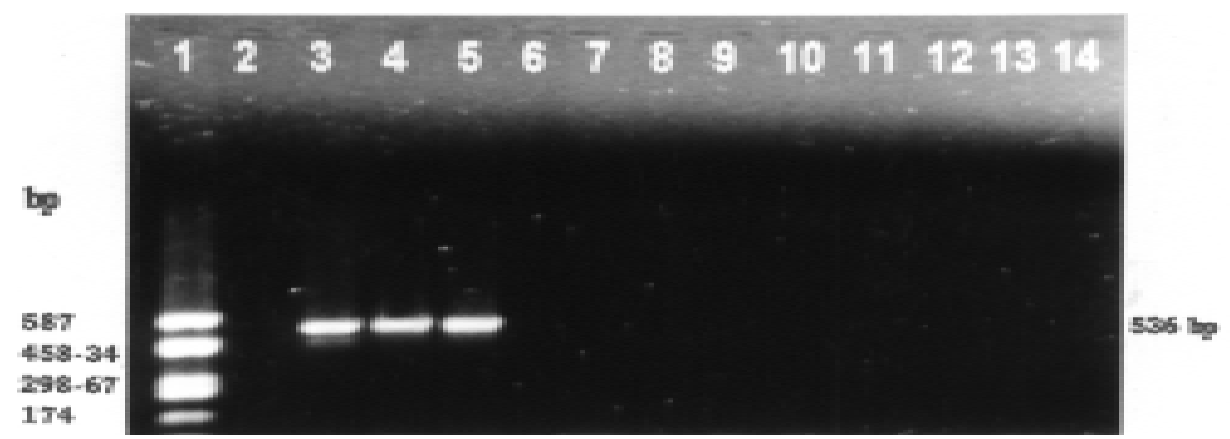

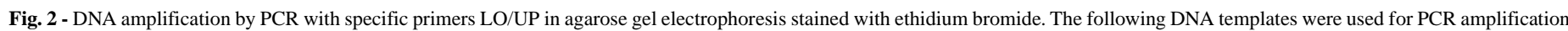

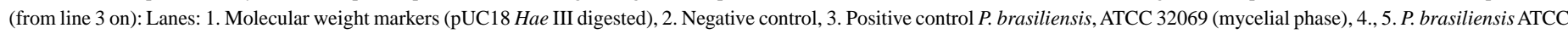

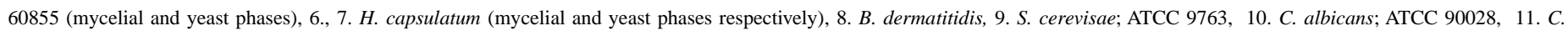
neoformans; ATCC 90112, 12. S. schenckii, 13. A. fumigatus, 14. Negative control. 


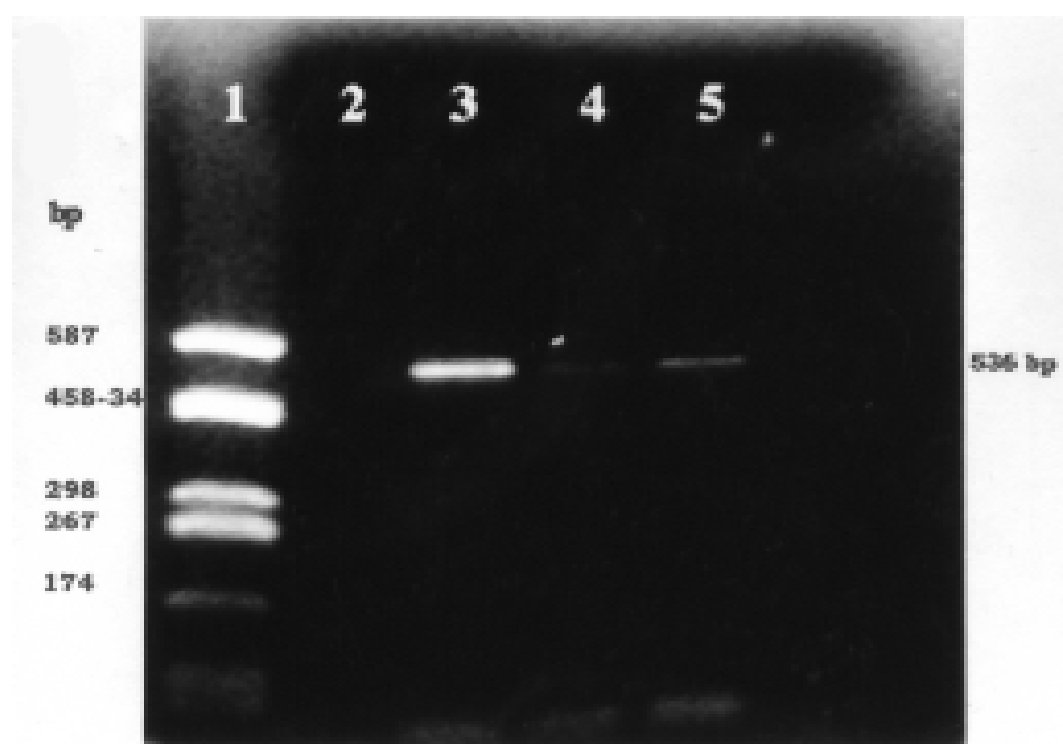

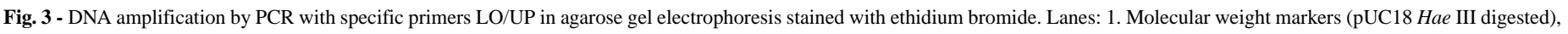
2. Negative control, 3. Positive control P. brasiliensis, 4. \& 5. Products of amplification from P. brasiliensis DNA extracted from soil.

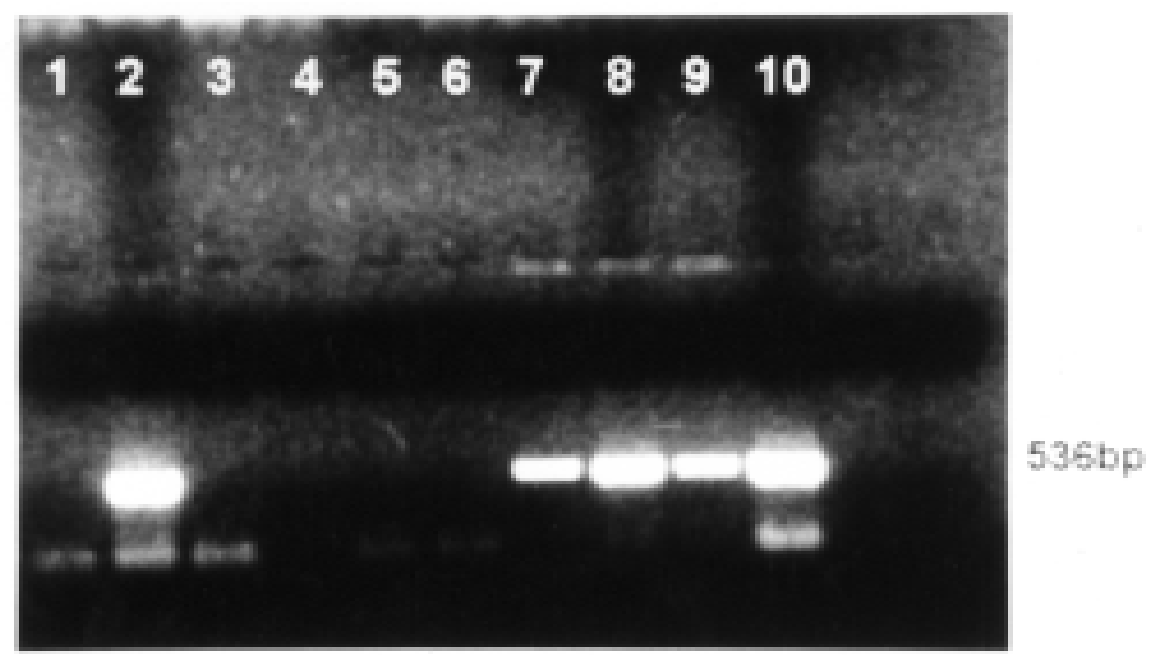

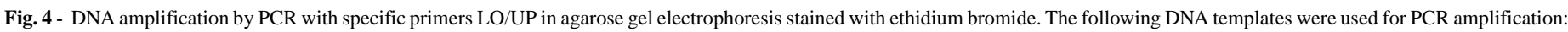

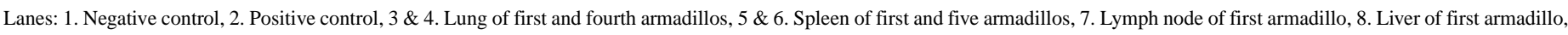
9. Lung of mouse inoculated with lymph node from the same armadillo, 10. Liver of mouse inoculated with armadillo's liver.

\section{DISCUSSION}

This report describes a method for amplification of $P$. brasiliensis genes through the use of PCR. This technology has previously been employed in the identification of other clinically important pathogens $s^{13,29}$, as well as of $P$. brasiliensis in an animal model ${ }^{13}$. In the later study, authors inoculated $5.8 \times 10^{6}$ yeast cells and obtained positive amplicons from the animals' sera 8 weeks afterwards; the level of sensitivity was $10 \mathrm{pg}$. PCR can also be similarly applied to the search of environmental microorganisms ${ }^{2,4}$.
The ability to extract DNA from fungal cells through mechanical disruption techniques and the use of SDS buffer and phenol for nucleic acid extraction, proves adequate for biochemical and/or genetic analyses and is also effective when obtaining DNA products of high quality ${ }^{30}$.

The gene codifying for the main $P$. brasiliensis antigenic protein of $43 \mathrm{kDa}$ was the first to be cloned and characterized ${ }^{8}$. This protein albeit not the recombinant one, has been widely employed as an antigen in the diagnosis of $\mathrm{PCM}^{7}$. The primers obtained from this gene sequence (gp431/gp43-2) have been shown to be highly specific for the amplification of 


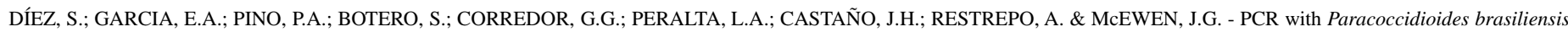
specific primers: potential use in ecological studies. Rev. Inst. Med. trop. S. Paulo, 41(6): 351-357, 1999.

P. brasiliensis DNA, and they were used to corroborate the positive findings in the armadillo's studies ${ }^{8}$. Similar results have been obtained using the gene that codifies for the $27 \mathrm{kDa}$ antigen protein which was cloned and characterized in our laboratory ${ }^{19,23}$. With the use of these primers it has been possible to detect low concentrations of fungal DNA (3pg, equivalent to 90 cells). We have also tested the mRNA levels of this $27 \mathrm{kDa}$ protein in different fungal cultures by Northern blot analysis and demonstrated that this protein mRNA is exclusively transcribed in P. brasiliensis (Figure 1).

Isolation of $P$. brasiliensis from soils by means of conventional techniques such as culture and animal inoculation, has low reproducibility $^{6}$. In order to improve these conditions, we standardized the PCR methodology in artificially P. brasiliensis contaminated soils samples, an important step in the search of its precise ecological niche and its possible use for future epidemiological studies. The main problem in the search of fungal DNA in soils by PCR, is the presence of inhibitors contained in these samples. Soils with high organic contents have humic acids with phenolic groups, which exhibit similar solubility to that of the DNA. As a consequence, they are not totally removed during classical extraction protocols and remain as contaminants in the final DNA preparation $^{4,20}$. An alternative to eliminate the presence of inhibitors is to consider that there are important differences in the size of DNA macromolecules and most common soluble PCR inhibitors; these inhibitors are effectively removed from the agarose blocks by diffusion during the washing steps, whereas genomic DNA remains trapped ${ }^{20}$. In our study, the PCR detection limit for P. brasiliensis species-specific sequences from soils, proved to be $40 \mathrm{ng}$ of DNA extracted from $1 \mathrm{~g}$ of soil (approximately $1.2 \times 10^{6}$ cells).

The infection with $P$. brasiliensis has been established in the ninebanded armadillo $D$. novemcinctus, an animal amply distributed in Latin America where it occupies areas that coincide, at least partly, with the paracoccidioidomycosis endemic regions. Additionally, in the armadillo's burrows, the environmental conditions would increase the possibilities for a stable fungal microniche ${ }^{12}$.

The positive fungal amplification obtained in some organs of a culture-positive armadillo, as well from tissues of another three culturenegative armadillos, suggest that PCR is not only a more sensitive technique than the conventional ones used with the same purpose ${ }^{9}$, but has also some advantages over culture of non sterile organs, such as lungs, usually heavily contaminated with various microorganisms. In one of the armadillos, the results obtained by PCR was confirmed by isolation of the agent in culture, the gold standard technique. The latter supports previous findings by other authors ${ }^{3,9,21}$, indicating that $P$. brasiliensis, can be isolated not only from humans samples, but also from armadillos, such as the one captured in an endemic area of Colombia 9 . The fact that only one armadillo from the 5 studied, was positive for culture while 3 revealed to be infected by DNA amplification, tends to suggest that PCR is indeed a more sensitive technique ${ }^{16}$.

The results reported here suggest that the PCR amplification of $P$. brasiliensis DNA by the use of species-specific primers, may play an important role in the search of this fungus habitat and also for future epidemiological studies. At present analysis of soil samples obtained from different endemic areas in Colombia and Brazil is being pursued. Several questions arise from this study, such as: how do armadillos get infected?. Once the microniche is detected, what environmental measures could be taken to avoid human infection?. Answers to these and other questions would require further explorations.

\section{RESUMO}

\section{PCR com «primers» específicos de Paracoccidioides brasiliensis: uso potencial em estudos ecológicos}

O microambiente adequado do Paracoccidioides brasiliensis não foi ainda bem esclarecido, talvez porque os métodos utilizados não sejam suficientemente sensíveis. Aplicamos com este propósito, a reação em cadeia da polimerase (PCR) usando três jogos de primers específicos do P. brasiliensis, correspondendo a dois dos genes do P. brasiliensis. Este fungo, assim como outros fungos, foram cultivados e seus DNAs obtidos por ruptura mecânica e purificados com mistura de fenol-clorofórmio com álcool isoamílico. Os DNAs serviram para a reação de PCR utilizando-se primers específicos para dois dos genes do $P$. brasiliensis que codificam para as proteínas antigênicas, denominadas, $27 \mathrm{kDa}$ e 43 $\mathrm{kDa}$. O limite mínimo de detecção para o gene $27 \mathrm{kDa}$ foi de $3 \mathrm{pg}$. A amplificação para os dois genes foi positiva só com o DNA do $P$. brasiliensis; além disso, o mRNA para o gene de $27 \mathrm{kDa}$ estava presente apenas no material do P. brasiliensis, como mostrado pela análise por Northern-blot. A padronização da técnica do PCR permitiu a amplificação do DNA do P. brasiliensis em solos contaminados artificialmente com o fungo e em tecidos de tatus infectados na natureza. Estes resultados indicam que a técnica do PCR podería ter um papel muito importante na pesquisa do habitat do $P$. brasiliensis e, além disso, podería ser utilizada em outros estudos ecológicos.

\section{ACKNOWLEDGEMENT}

This work was supported by COLCIENCIAS, Santafé de Bogotá, Colombia, project number 2213-05-386-96. The kind cooperation offered by the personnel in the Laboratory of Mycology is greatly appreciated.

\section{REFERENCES}

1. ALBORNOZ, M.B. - Isolation of Paracoccidioides brasiliensis from rural soil in Venezuela. Sabouraudia, 2: 248-252, 1971.

2. ATLAS, R.M.; SAYLER, G.; BURLAGE, R.S. \& BEJ, A.M. - Molecular approaches for environmental monitoring of microorganisms. Biotechniques, 12: 706-717, 1992.

3. BAGAGLI, E.; SANO, A.; COELHO, K.I. et al. - Isolation of Paracoccidioides brasiliensis from armadillos (Dasypus noveminctus) captured in an endemic area of paracoccidioidomycosis. Amer. J. trop. Med. Hyg., 58: 505-512, 1998.

4. BEJ, A.K.; MAHBUBANI, M.H.; DICESARE, J.L. \& ATLAS, R.M. - Polymerase chain reaction-gene probe detection of microorganisms by using filter-concentrated samples. Appl. environ. Microbiol., 57: 3529-3534, 1991.

5. BOWMAN, B.A. - A model PCR/probe system for the identification of fungal pathogens In: PERSING, D. H.; SMITH, T. F.; TENONER, F. C. \& WHITE, T. J., ed. Diagnostic molecular Microbiology. Washington, American Society for Microbiology, 1993. p. $423-430$.

6. BRUMMER, E.; CASTAÑEDA, E. \& RESTREPO, A. - Paracoccidioidomycosis: an update. Clin. Microbiol. Rev., 6: 89-117, 1993.

7. CAMARGO, Z.P.; UNTERKIRCHER, C. \& TRAVASSOS, L.R. - Identification of antigenic polypeptides of Paracoccidioides brasiliensis by immunobloting. J. med. vet. Mycol., 27: 407-412, 1989. 


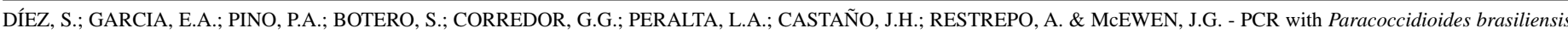
specific primers: potential use in ecological studies. Rev. Inst. Med. trop. S. Paulo, 41(6): 351-357, 1999.

8. CISALPINO, P.S.; PUCCIA, R.; YAMAUCHI, L.M. et al. - Cloning, characterization, and epitope expression of the major diagnostic antigen of Paracoccidioides brasiliensis. J. biol. Chem., 271: 4553-4560, 1996.

9. CORREDOR, G.G.; CASTAÑO, J.H.; PERALTA, L.A. et al. - Isolation of Paracoccidioides brasiliensis from the nine-banded armadillo Dasypus novemcinctus, in an endemic area for paracoccidioidomycosis in Colombia. Rev. iberoamer. Micol. 16: $37-41,1999$

10. ESPINEL-INGROFF, A. \& KERKERING, T.M. - Spectrophotometric methods of inoculum preparation for the in vitro testing of filamentous fungi. J. clin. Microbiol., 29: $393-394,1991$

11. FERREIRA, M.S.; FREITAS, L.H.; LACAZ, C.S. et al. - Isolation and characterization of a Paracoccidioides brasiliensis strain from a dogfood contaminated with soil in Uberlandia, Brazil. J. med. vet. Mycol., 28: 253-256, 1990.

12. FORJAZ, M.H.H. - Estudo da epidemiología da Paracoccidioidomicose. Rastreamento de áreas endêmicas e de "reserváreas" no Brasil, através do traçado do perfil migratório-residencial-profissional, de pacientes diagnosticados em São Paulo. São Paulo, 1989. (Thesis - Escola Paulista de Medicina/UNIFESP).

13. GOLDANI, L.Z. \& SUGAR, A.M. - Short report: use of the polymerase chain reaction to detect Paracoccidioides brasiliensis in murine paracoccidioidomycosis. Amer. J. trop. Med. Hyg., 58: 152-153, 1998.

14. GROSE, E. \& TAMSITT, J.R. - Paracoccidioides brasiliensis recovered from the intestinal tract of 3 bats (Artibeus lituratus) in Colombia. Sabouradia, 4: 124, 1965.

15. GUEZUELE, E. - Aislamiento de Paracoccidioides sp. de heces de pinguino de la Antártida. In: ENCUENTRO INTERNACIONAL SOBRE PARACOCCIDIOIDOMICOSIS, 4., Caracas, 1989. Proceedings. p. B2

16. INNIS, M.A.; GELFAND, D.H.; SNINSKY, J.J. \& WHITE, T.J. - PCR protocols. San Diego, Academic Press, 1990.

17. JOHNSTON, C.G. \& AUST, S.D. - Detection of Phynerochaetae chrysosporium in soi by PCR and restriction enzyme analysis. Appl. environ. Microbiol., 60: 2350-2354, 1994.

18. MCEWEN, J.G.; GARCIA, A.M.; ORTIZ, B.L. et al. - In search of the natural habitat of Paracoccidioides brasiliensis. Arch. med. Res., 26: 305-306, 1995.

19. MCEWEN, J.G.; ORTIZ, B.L.; GARCIA, A.M. et al. - Molecular cloning, nucleotide sequencing, and characterization of a 27-kDa antigenic protein from Paracoccidioides brasiliensis. Fungal Genet. Biol., 20: 125-131, 1996.
20. MOREIRA, D. - Efficient removal of PCR inhibitors using agarose-embedded DNA preparations. Nucleic Acids Res., 26: 3309-3310, 1998

21. NAIFF, R.D.; FERREIRA, L.C.L.; BARRETT, T.V. et al. - Paracoccidioidomicose enzoótica em tatus (Dasypus novemcinctus) no Estado do Pará. Rev. Inst. Med. trop. S. Paulo, 28: 19-27, 1986.

22. NEGRONI, P. - El Paracoccidioides brasiliensis vive saprofíticamente en el suelo argentino. Pren. méd. argent., 53: 2381-2382, 1966.

23. ORTIZ, B.L.; DÍEZ, S.; URÁN, M.E. et al. - Use of 27-Kilodalton recombinant protein from Paracoccidioides brasiliensis in serodiagnosis of paracoccidioidomycosis. Clin diagn. Lab. Immunol., 5: 826-830, 1998.

24. RESTREPO, A. - Ecology of Paracoccidioides brasiliensis. In: FRANCO, M.; LACAZ, C.S.; RESTREPO, A. \& DEL NEGRO G., ed. Paracoccidioidomycosis. Boca Raton, CRC Press, 1994. p. 121-130.

25. RESTREPO, A. \& JIMENEZ, B. - Growth of Paracoccidioides brasiliensis yeast phase in a chemically defined medium. J. clin. Microbiol., 12: 279-281, 1980.

26. SAMBROOK, J.; FRITSCH, E.F. \& MANIATIS, T. - Molecular cloning: a laboratory manual. 2. ed. New York, Cold Spring Harbor, 1989. v: 1

27. SILVA-VERGARA, M.L.; MARTINEZ, R.; CHADU, A. et al. - Isolation of a Paracoccidioides brasiliensis strain from the soil of a coffee plantation in Ibiá, State of Minas Gerais, Brazil. Med. Mycol., 36: 37-42, 1998.

28. TSAI, Y.L. \& OLSON, G.H. - Rapid method for direct extraction of DNA from soil and sediment. Appl. environ. Microbiol., 57: 1070-1074, 1991.

29. VAN BURIK, J.A.H.; MYERSON, D.; SCHRECKHISE, R.W. \& BOWDEN, R.A. Panfungal PCR assay for detection of fungal infection in human blood specimens. J. clin. Microbiol., 36: 1169-1175, 1998.

30. VAN BURIK, J.A.H.; SCHRECKHISE, R.W.; WHITE, T.C.; BOWDEN, R.A. \& MYERSON, D. - Comparison of six extraction techniques for isolation of DNA from filamentous fungi. Med. Mycol., 36: 299-303, 1998.

31. VESCIO, P.A. \& NIERZWICKI-BAUER, S.A. - Extraction and purification of PCR amplifiable DNA from lacustrine subsurface sediments. J. microbiol. Meth., 21: 225-233, 1995.

Received: 02 July 1999

Accepted: 22 October 1999 